\title{
Fecal indicators and bacterial pathogens in bottled water from Dhaka, Bangladesh
}

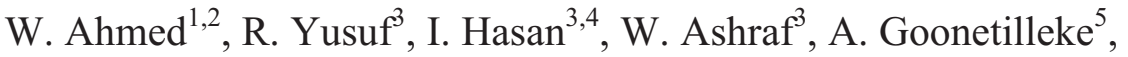 \\ S. Toze ${ }^{1}$, T. Gardner ${ }^{1,2}$ \\ ${ }^{1}$ CSIRO Land and Water, Ecosciences Precinct, Boggo Road, Brisbane, Australia. \\ ${ }^{2}$ Department of Environment and Resource Management, Indooroopilly, Brisbane, Australia. \\ ${ }^{3}$ School of Life Sciences, Independent University Bangladesh, Dhaka, Bangladesh. \\ ${ }^{4}$ Department of Biochemistry and Molecular Biology, Rajshahi University, Rajshahi, Bangladesh. \\ ${ }^{5}$ Science and Engineering Faculty, Queensland University of Technology, Brisbane, Australia.
}

Submitted: August 25, 2011; Approved: July 2, 2012.

\begin{abstract}
Forty-six bottled water samples representing 16 brands from Dhaka, Bangladesh were tested for the numbers of total coliforms, fecal indicator bacteria (i.e., thermotolerant Escherichia coli and Enterococcus spp.) and potential bacterial pathogens (i.e., Aeromonas hydrophila, Pseudomonas aeruginosa, Salmonella spp., and Shigella spp.). Among the 16 brands tested, 14 (86\%), ten (63\%) and seven (44\%) were positive for total coliforms, E. coil and Enterococcus spp., respectively. Additionally, a further nine (56\%), eight (50\%), six (37\%), and four (25\%) brands were PCR positive for A. hydrophila lip, P. aeruginosa ETA, Salmonella spp. invA, and Shigella spp. ipaH genes, respectively. The numbers of bacterial pathogens in bottled water samples ranged from $28 \pm 12$ to $600 \pm 45$ (A. hydrophila lip gene), $180 \pm 40$ to $900 \pm 200$ (Salmonella spp. invA gene), $180 \pm 40$ to $1,300 \pm 400$ ( $P$. aeruginosa ETA gene) genomic units per L of water. Shigella spp. ipaH gene was not quantifiable. Discrepancies were observed in terms of the occurrence of fecal indicators and bacterial pathogens. No correlations were observed between fecal indicators numbers and presence/absence of $A$. hydrophila lip $(\mathrm{p}=0.245)$, Salmonella spp. invA $(\mathrm{p}=0.433)$, Shigella spp. ipaH gene $(\mathrm{p}=0.078)$, and $P$. aeruginosa ETA $(\mathrm{p}=0.059)$ genes. Our results suggest that microbiological quality of bottled waters sold in Dhaka, Bangladesh is highly variable. To protect public health, stringent quality control is recommended for the bottled water industry in Bangladesh.
\end{abstract}

Key words: bottled water, fecal indicator bacteria, quantitative PCR, bacterial pathogens, public health risk.

\section{Introduction}

Over the past two decades the consumption of bottled water, commonly known as "mineral water" has increased substantially in Bangladesh. The most significant impetus for this phenomenon can be attributed to the frequent outbreaks of diarrhoeal and other diseases resulting from microbial and chemical contamination of drinking water sources (Chakraborti et al., 2010; Islam et al., 2006). A common perception is that bottled water is safe for consumption. This is largely because bottled water is marketed as "pure and clean" by manufacturers, and therefore, con- sumers prefer bottled water over other drinking water sources. Bottled water has also been marketed as ideal for infants and immunocompromised individuals in order to avoid to exposure to potential pathogens which are detrimental to human health (Warburton et al., 1992).

Despite the perceived purity, the microbiological quality of bottled water has been questioned over the years (Kassenga 2007, Rosenberg 2003). Several research studies have reported the presence of fecal indicator and heterotrophic bacteria with levels exceeding drinking water guidelines (Bartram et al., 2004; Kassenga 2007; Svagzdiene et al., 2010). Potential pathogens such as Aeromonas spp. 
(Venieri et al., 2010), Staphylococcus aureus (Leclerc et al., 1995), Pseudomonas spp. (Svagzdiene et al., 2010), Shigella spp. (Khan et al., 1992), Salmonella spp. (Warburton et al., 1994), Vibrio cholerae (Blake et al., 1997) have been detected in bottled water. Local newspapers in Bangladesh too, have expressed their concerns that some brands of bottled water may not be safe for consumption (Jamir 2009). There are suspicions that, with some exception, the bottles are filled with water of unsatisfactory quality. Unfortunately, no comprehensive study has been conducted to date to determine the quality of the bottled water being marketed in Bangladesh.

Pathogenic microorganisms in bottled water can multiply during storage and can reach a level which can be detrimental to consumers (Korzeniewska et al., 2005; Messi et al., 2002). For example, Escherichia coli, Pseudomonas spp., and Salmonella spp. have been demonstrated to survive and multiply in bottled water (Warburton et al., 1994). To ensure that bottled water is safe for drinking, quality standards have to be strictly enforced. According to the European Community Directive (European Community 1980), total coliforms, E. coli, Enterococcus spp., Pseudomonas aeruginosa and parasites should not be detected in $250 \mathrm{~mL}$ of bottled water, whereas, World Health Organization (WHO 2004) recommends the number of fecal coliforms should be zero in water used for drinking (WHO 2004).

The primary aim of this study was to assess the microbiological quality of commonly available bottled water in Dhaka, Bangladesh. Different brands of bottled water samples were tested for the numbers of potential bacterial pathogens (A. hydrophila, Salmonella spp. Shigella spp., and $P$. aeruginosa) using Quantitative PCR (qPCR) along with the enumeration of total coliforms and fecal indicator bacteria, namely E. coli and Enterococcus spp. using culture-based methods. Finally, the data was analysed to determine the correlation between fecal indicators and the occurrence of potential bacterial pathogens in bottled water samples.

\section{Materials and Methods}

\section{Sources of samples}

A total of, 46 polyethylene terephthalate (PET) processed bottled water representing 16 domestic brands were purchased from retail outlets situated in Dhanmondi, Gulshan, Mirpur, Puran Dhaka and Uttara areas of Dhaka, Bangladesh between July - August 2009. Up to five samples were collected for each brand. For this study, bottled water was defined as any potable water that is manufactured or processed, distributed or offered for sale for human consumption.

\section{Isolation and enumeration of fecal indicators}

The membrane filtration method was used to process samples $(100 \mathrm{~mL}$ each) for total coliforms and fecal indicator bacterial enumeration. Samples were filtered through $0.45 \mu \mathrm{m}$ nitrocellulose membranes (Advantec, Tokyo, Japan) and placed on chromocult (Merck, Darmstadt, Germany), modified mTEC agar (Difco, Detroit, Mi), and membrane-Enterococcus indoxyl- $\beta$-D-glucoside (mEI) agar (Difco) for the isolation of total coliforms, thermotolerant E. coli, and Enterococcus spp., respectively. Chromocult agar plates were incubated at $37{ }^{\circ} \mathrm{C}$ for $24 \mathrm{~h}$. Modified mTEC agar plates were incubated at $35^{\circ} \mathrm{C}$ for $2 \mathrm{~h}$ to recover stressed cells, followed by incubation at $44{ }^{\circ} \mathrm{C}$ for $22 \mathrm{~h}$, and mEI agar plates were incubated at $41^{\circ} \mathrm{C}$ for $48 \mathrm{~h}$. All water samples were tested in triplicate.

\section{DNA extraction}

For PCR analysis of potential bacterial pathogens, each bottled water sample (i.e., $1 \mathrm{~L}$ ) was filtered through a $0.45 \mu \mathrm{m}$ nitrocellulose membrane. The membranes were carefully washed with Sodium Chloride-Tris-EDTA (STE) buffer using a pipette $(0.1 \mathrm{~mol} / \mathrm{L} \mathrm{NaCl}, 10 \mathrm{mmol} / \mathrm{L}$ Tris, and $1 \mathrm{mmol} / \mathrm{L}$ EDTA (pH 7.6) and the buffer containing filtrates were transferred to $2 \mathrm{~mL}$ screw cap tubes. The tubes were subjected to centrifugation at $8,000 \mathrm{~g}$ for $30 \mathrm{~min}$ at $4{ }^{\circ} \mathrm{C}$. The supernatant was discarded, and the pellet was resuspended in $200 \mu \mathrm{L}$ PBS. DNA was extracted using the DNeasy Blood and Tissue Kit (Qiagen, Valencia, Calif.), and eluted DNA was stored at $-80^{\circ} \mathrm{C}$ until use.

\section{Specificity of PCR primers}

In this study, PCR detection of potential pathogenic bacteria was undertaken using previously published primers and PCR assays (Cascon et al., 1996; Chiu and Ou 1996; Khan and Cerniglia 1994; Thiem et al., 2004). The primer sequences for corresponding target genes are shown in Table 1. Primer specificity was determined by searching for similar sequences in microbial genomes using the Basic Local Alignment Search Tool (BLAST) program (http://www. ncbi.nlm.nih.gov/BLAST/). This ensured that no homology was observed with known gene sequences of other pathogenic microorganisms commonly found in environmental waters. The cross-reactivity of each primer set was also evaluated by testing DNA isolated from other non target species commonly found in water, including $B$. vulgatus ATCC 8482, A. hydrophila ATCC 7966, C. coli ATCC 43478, L. pneumophila ATCC 33152, and Salmonella typhimurium ATCC 14028. C. jejuni NCTC 11168 , C. perfringens ATCC 13124, E. coli ATCC 9637, Enterococcus faecalis ATCC 19433, Enterococcus faecium ATCC 19434, Pseudomonas aeruginosa ATCC 27853, Cryptosporidium ATCC PRA-67D, Citrobacter freundii ATCC 8090, Shigella sonnei ATCC 29930, 
Table 1 - Target genes, primers and cycling parameters used for bacterial pathogen detection.

\begin{tabular}{|c|c|c|c|c|}
\hline Target & Primer sequence $\left(5^{\prime}-3^{\prime}\right)$ & Cycling parameters & $\begin{array}{l}\text { Amplicons } \\
\text { size (bp) }\end{array}$ & Reference \\
\hline A. hydrophila lip gene & $\begin{array}{l}\text { AAC CTG GTT CCG CTC AAG CCG TT }{ }^{a} \\
\text { TTG CTC GCC TCG GCC CAG CAG CT }\end{array}$ & $\begin{array}{l}8 \mathrm{~min} \text { at } 95^{\circ} \mathrm{C}, 30 \text { cycles of } 94^{\circ} \mathrm{C} \\
\text { for } 1 \mathrm{~min}, 62^{\circ} \mathrm{C} \text { for } 1 \mathrm{~min} \text {, and } \\
72{ }^{\circ} \mathrm{C} \text { for } 1.5 \mathrm{~min}\end{array}$ & 760 & $\begin{array}{l}\text { Cascon et al. } \\
1996\end{array}$ \\
\hline Salmonella spp. invA gene & $\begin{array}{l}\text { ACA GTG CTC GTT TAC GAC CTG AAT }{ }^{a} \\
\text { AGA CGA CTG GTA CTG ATC GAT AAT }\end{array}$ & $\begin{array}{l}8 \text { min at } 95^{\circ} \mathrm{C}, 30 \text { cycles of } 94^{\circ} \mathrm{C} \\
\text { for } 30 \mathrm{~s}, 59^{\circ} \mathrm{C} \text { for } 35 \mathrm{~s} \text {, and } 72^{\circ} \mathrm{C} \\
\text { for } 2 \mathrm{~min}\end{array}$ & 244 & $\begin{array}{l}\text { Chiu and Ou } \\
1996\end{array}$ \\
\hline Shigella spp. ipaH gene & $\begin{array}{l}\text { CCT TTT CCG CGT TCC } \text { TTG }^{a} \\
\text { CGG AAT CCG GAG GTA TTG }\end{array}$ & $\begin{array}{l}8 \text { min at } 95^{\circ} \mathrm{C}, 35 \text { cycles of } 95^{\circ} \mathrm{C} \\
\text { for } 30 \mathrm{~s}, 60^{\circ} \mathrm{C} \text { for } 1 \mathrm{~min} .\end{array}$ & 63 & $\begin{array}{l}\text { Thiem et al. } \\
2004\end{array}$ \\
\hline P. aeruginosa ETA gene & $\begin{array}{l}\text { GAC AAC GCC CTC AGC ATC CCA GC }{ }^{a} \\
\text { CGC TGG CCC ATT CGC TCC AGC GCT }\end{array}$ & $\begin{array}{l}8 \mathrm{~min} \text { at } 95^{\circ} \mathrm{C}, 35 \text { cycles of } 94^{\circ} \mathrm{C} \\
\text { for } 1 \mathrm{~min}, 68^{\circ} \mathrm{C} \text { for } 1 \mathrm{~min} \text {, and } \\
72^{\circ} \mathrm{C} \text { for } 1 \mathrm{~min}\end{array}$ & 396 & $\begin{array}{l}\text { Khan et al. } \\
1994\end{array}$ \\
\hline
\end{tabular}

${ }^{a}$ Forward primer. ${ }^{b}$ Reverse primer.

Shigella flexineri NCTC 8296 and Klebsiella pneumoniae ATCC 31314.

\section{Positive controls and qPCR of bacterial pathogens}

A. hydrophila ATCC 7966, Salmonella typhimurium ATCC 14028, Shigella flexineri NCTC 8296, and $P$. aeruginosa ATCC 27853 were used as PCR positive controls. Standards for qPCR of the A. hydrophila lip, Salmonella spp. invA, Shigella spp. ipaH, and P. aeruginosa ETA genes were prepared from the genomic DNA. The concentration of genomic DNA was determined by measuring the $A_{260}$ using a Beckman Coulter DU 730 spectrophotometer. The genomic copies were calculated, and a 10-fold dilution ranging from $10^{6}$ to $10^{\circ}$ copies per $\mu \mathrm{L}$ of DNA extract was prepared from the genomic DNA, and stored at $-20^{\circ} \mathrm{C}$ until use. Amplification was performed in $25 \mu \mathrm{L}$ PCR reaction mixtures containing 12.5 $\mu \mathrm{L}$ SuperMix (SYBR Green iQ Supermix, Bio-Rad Laboratories, Calif), $300 \mathrm{nM}$ of each primer, and $2 \mu \mathrm{L}$ of template DNA. For each PCR experiment, corresponding positive (i.e., target DNA) and negative controls (sterile water) were included. The PCR was performed using the Bio-Rad iQ5 (Bio-Rad Laboratories). Cycling parameters for the target bacterial pathogens are shown in Table 1.

\section{PCR limit of detection (LOD) and DNA sequencing}

To determine the PCR lower limits of detection (LOD), a range of known gene copies (i.e., $5 \times 10^{3}-5 \times 10^{0}$ ) of each target gene was tested. The lowest concentration of gene copies detected consistently in replicate assays was considered PCR LOD. To verify the identity of the PCR products obtained from water samples, up to 3 PCR-amplified products from each target were purified using the QIAquick PCR purification kit, as recommended by the manufacturer (Qiagen), and cloned in duplicate into the pGEM-T Easy Vector system (Promega, Madison, Wis.), as recommended by the manufacturer. Plasmids were extracted using the QIAprep Spin-Miniprep kit (Qiagen). Bidirectional sequences were obtained using T7 and SP6 long sequencing primer targeting sites on either side of the insert. DNA sequencing was carried out at the Australian Genome Research Facility (St. Lucia, Queensland, Australia). The sequences were analysed using Jellyfish Software and verified against the published sequence.

\section{Statistical analysis}

A binary logistic regression (BLR) (SPSS version 12.0) analysis was performed to obtain correlations between the presence/absence of the pathogens with the numbers of fecal indicator bacteria (i.e., E. coli and Enterococcus spp.).

\section{Results and Discussion}

\section{Specificity of PCR primers and PCR limit of detection}

Before the application of PCR based methods, the specificity of each primer and the qPCR LOD for each assay was determined. The primers used in this study did not amplify any PCR products other than those target bacterial pathogens. The qPCR LOD were as low as 5 gene copies for the A. hydrophila, P. aeruginosa, L. pneumophila, Salmonella typhimurium, and $S$. flexineri.

\section{Numbers of fecal indicators and potential bacterial pathogens}

Among the 46 bottled water samples tested from the 16 brands, $36(78 \%)$ samples were found to be positive for at least one microorganism tested in this study. The remaining $10(22 \%)$ samples did not yield any positive results for total coliforms, fecal indicators and bacterial pathogens. Among the 16 brands of bottled water samples tested, 14 $(86 \%)$ brands were found to be positive for total coliforms (Table 2). The numbers of total coliforms in positive brands ranged from $3 \pm 2$ to $43 \pm 7$ cfu per $100 \mathrm{~mL}$ of water. Ten $(63 \%)$ brands were found to be positive for thermotolerant E. coli (Table 2) and exceeded guideline value of zero fecal coliforms per $100 \mathrm{~mL}$ of drinking water (WHO 2004). The 
Table 2 - Numbers of total coliforms, fecal indicators and pathogenic bacteria in bottled water samples in Dhaka, Bangladesh.

\begin{tabular}{|c|c|c|c|c|c|c|c|c|}
\hline \multirow[t]{2}{*}{ Brands } & \multirow{2}{*}{$\begin{array}{l}\text { Sample } \\
\text { no. }\end{array}$} & \multicolumn{7}{|c|}{ Numbers (mean \pm SD) of total coliforms fecal indicators (cfu per $100 \mathrm{~mL}$ ) and pathogens (genomic units per L) in bottled water } \\
\hline & & Total coliforms & E. coli & $\begin{array}{c}\text { Enterococcus } \\
\text { spp. }\end{array}$ & $\begin{array}{l}\text { A. hydrophila lip } \\
\text { gene }\end{array}$ & $\begin{array}{l}\text { Salmonella spp. } \\
\text { invA gene }\end{array}$ & $\begin{array}{c}\text { Shigella spp. } \\
\text { ipaH gene }\end{array}$ & $\begin{array}{l}\text { P. aeruginosa } \\
\text { ETA gene }\end{array}$ \\
\hline \multirow[t]{3}{*}{ A } & 1 & ND & ND & $3 \pm 2$ & ND & ND & ND & ND \\
\hline & 3 & ND & ND & ND & ND & ND & $+^{a}$ & ND \\
\hline & 5 & ND & ND & $3 \pm 2$ & ND & ND & ND & ND \\
\hline B & 1 & $6 \pm 2$ & ND & ND & $230 \pm 24$ & $+^{a}$ & ND & $1300 \pm 400$ \\
\hline \multirow[t]{2}{*}{$\mathrm{C}$} & 1 & $14 \pm 4$ & $3 \pm 2$ & ND & ND & ND & ND & ND \\
\hline & 2 & $8 \pm 3$ & ND & $3 \pm 2$ & ND & ND & ND & ND \\
\hline \multirow[t]{4}{*}{$\mathrm{D}$} & 1 & ND & ND & ND & $28 \pm 12$ & ND & ND & ND \\
\hline & 2 & $8 \pm 4$ & $3 \pm 2$ & ND & $+^{a}$ & ND & ND & $+{ }^{a}$ \\
\hline & 3 & $11 \pm 2$ & $3 \pm 2$ & ND & $450 \pm 180$ & ND & ND & ND \\
\hline & 4 & $34 \pm 7$ & $10 \pm 2$ & $3 \pm 2$ & $+^{a}$ & $300 \pm 48$ & ND & ND \\
\hline \multirow[t]{2}{*}{$\mathrm{E}$} & 2 & $11 \pm 4$ & ND & ND & $+^{a}$ & ND & ND & ND \\
\hline & 3 & ND & ND & $3 \pm 2$ & ND & ND & ND & ND \\
\hline \multirow[t]{4}{*}{$\mathrm{F}$} & 1 & ND & ND & $3 \pm 2$ & ND & ND & ND & ND \\
\hline & 2 & ND & ND & ND & ND & $430 \pm 110$ & ND & ND \\
\hline & 3 & $3 \pm 2$ & ND & $3 \pm 2$ & ND & ND & $+^{a}$ & ND \\
\hline & 4 & ND & ND & ND & ND & ND & ND & $700 \pm 200$ \\
\hline G & 1 & $7 \pm 3$ & $3 \pm 2$ & ND & $60 \pm 20$ & ND & ND & $+{ }^{a}$ \\
\hline \multirow[t]{4}{*}{$\mathrm{H}$} & 1 & $\mathrm{ND}$ & ND & ND & $+^{a}$ & ND & ND & ND \\
\hline & 3 & $22 \pm 6$ & $14 \pm 3$ & ND & $+^{a}$ & ND & ND & ND \\
\hline & 4 & $8 \pm 1$ & $4 \pm 2$ & ND & $600 \pm 45$ & ND & ND & ND \\
\hline & 5 & $6 \pm 1$ & $3 \pm 2$ & ND & $+^{a}$ & ND & ND & ND \\
\hline I & 1 & $11 \pm 4$ & $3 \pm 2$ & $3 \pm 2$ & $+^{a}$ & ND & ND & ND \\
\hline $\mathrm{J}$ & 1 & ND & ND & ND & ND & ND & $+^{a}$ & $+^{a}$ \\
\hline \multirow[t]{3}{*}{ K } & 1 & $10 \pm 3$ & $3 \pm 2$ & ND & ND & ND & ND & ND \\
\hline & 2 & $19 \pm 3$ & $11 \pm 2$ & $3 \pm 2$ & ND & ND & ND & ND \\
\hline & 5 & $7 \pm 2$ & $3 \pm 1$ & $3 \pm 2$ & $+^{a}$ & ND & ND & ND \\
\hline $\mathrm{L}$ & 1 & $4 \pm 3$ & ND & $\mathrm{ND}$ & ND & ND & $+^{a}$ & ND \\
\hline \multirow[t]{2}{*}{ M } & 1 & $6 \pm 1$ & $3 \pm 2$ & ND & $+^{a}$ & ND & ND & $400 \pm 80$ \\
\hline & 2 & $14 \pm 2$ & $6 \pm 2$ & ND & ND & $+^{a}$ & ND & $+{ }^{a}$ \\
\hline \multirow[t]{4}{*}{$\mathrm{N}$} & 1 & $6 \pm 1$ & $3 \pm 2$ & ND & ND & ND & ND & ND \\
\hline & 2 & ND & ND & ND & $+^{a}$ & ND & ND & ND \\
\hline & 3 & $7 \pm 3$ & $3 \pm 2$ & ND & $230 \pm 70$ & ND & ND & ND \\
\hline & 5 & $8 \pm 4$ & $3 \pm 1$ & ND & ND & ND & ND & ND \\
\hline $\mathrm{O}$ & 1 & $11 \pm 3$ & $3 \pm 2$ & ND & ND & $+^{a}$ & ND & $+{ }^{a}$ \\
\hline \multirow[t]{2}{*}{$\mathrm{P}$} & 1 & $6 \pm 2$ & ND & ND & ND & $900 \pm 200$ & ND & $180 \pm 50$ \\
\hline & 2 & $11 \pm 5$ & $3 \pm 2$ & ND & ND & $180 \pm 40$ & ND & ND \\
\hline
\end{tabular}

ND: Not detected. ${ }^{a}$ Not quantifiable.

percentage of samples found positive for fecal indicators were higher in this study compared to past research studies (Bharath et al., 2003; Rivilla and Gonzalez 1988), thus pointing to microbial contamination of bottled water. The numbers of $E$. coli in positive brands ranged between
$2.6 \pm 2$ to $14 \pm 3$ cfu per $100 \mathrm{~mL}$. Similarly, seven (44\%) out of 16 brands were positive for Enterococcus spp. The number of Enterococcus spp. in these samples/brands ranged between $2.6 \pm 2$ to $3 \pm 2 \mathrm{cfu}$ per $100 \mathrm{~mL}$. Additionally, among the 16 brands, nine (56\%) were found to be positive 
for $A$. hydrophila lip gene. The number of brands positive for $P$. aeruginosa ETA, Salmonella spp. invA, and Shigella spp. ipa $H$ genes were eight $(50 \%)$, six (37\%), and four $(25 \%)$ brands, respectively. The numbers of bacterial pathogens ranged from $28 \pm 12$ to $600 \pm 45$ (A. hydrophila lip gene), $180 \pm 40$ to $900 \pm 200$ (Salmonella spp. invA gene), $180 \pm 40$ to $1,300 \pm 400$ (P. aeruginosa ETA gene) genomic units per L of water. Shigella spp. ipaH gene was not quantifiable.

A. hydrophila is known to cause septicemia and gastroenteritis in young children, elderly and immunocompromised people. The presence of Pseudomonas spp. and P. aeruginosa (Bharath et al., 2003; Hunter et al., 1990; Svagzdiene et al., 2010) has been previously reported in bottled water. Several Pseudomonas spp. can cause disease in humans. Pseudomonas cepacia is increasingly identified as a cause of serious chest infections in children with cystic fibrosis. A particular feature of $P$. aeruginosa is that it can multiply and very quickly reach harmful numbers, which can be detrimental to newborns and elderly patients. Besides being a primary cause of disease, $P$. aeruginosa is often monitored as an indicator of other bacterial contamination of fecal origin (Warburton et al., 1994). Legnani et al. (1999) isolated certain strains of Pseudonomas in the final rinsing water of a bottle washing machine at a mineral water plant. This highlights the risk that $P$. aeruginosa can pose in contaminating bottled water at the processing stage. Among the 16 brands tested one (6\%) was positive for at least the three target genes, eight $(50 \%)$ were positive for at least two target genes, and 15 (94\%) were positive for at least one target gene. We acknowledged that qPCR based methods were used in this study for the quantitative detection of bacterial pathogens because detection of pathogens in bottled water using culture-based methods can be difficult due to the viable but non-culturable (VBNC) state of the microorganisms. A major limitation of PCR based methods is its inability to distinguish between viable and non-viable cells. It is possible that some of PCR detected pathogens in this study were non viable pathogens.

The finding, however, that most of the bottled water brands were positive for either fecal indicators or one or more bacterial pathogens highlights potential health risks to consumers, especially the elderly, infants and immunocompromised patients in Bangladesh as these people are being encouraged via aggressive media advertising to consume bottled water as a safer alternative to tap water. Gastroenteritis caused by the identified pathogens following consumption of contaminated bottled water has been reported previously (Blake et al., 1977; Pavia 1987).

\section{Correlation between fecal indicators and occurrence of pathogens}

Discrepancies were observed in terms of the occurrence of fecal indicators and bacterial pathogens. For example, $15 \%$ and $26 \%$ of samples had no total coliforms and $E$. coli but were positive for one or more target pathogens. Similarly, 23\% of samples had no Enterococcus spp. but were positive for one or more target bacterial pathogens. Binary logistic regression analysis was used to identify whether any correlation exists between the numbers of fecal indicator bacteria (i.e., E. coil and Enterococcus spp.) and the presence/absence results of bacterial pathogens. For this analysis, E. coli and Enterococcus spp. numbers were pooled for comparison with the pathogenic bacteria. No correlations were observed between fecal indicator numbers and presence/absence of $A$. hydrophila lip $(\mathrm{p}=0.245)$, Salmonella spp. invA $(\mathrm{p}=0.433)$, Shigella spp. ipaH gene $(\mathrm{p}=0.078)$, and $P$. aeruginosa ETA $(\mathrm{p}=0.059)$ genes (Table 3). A recent study also reported that E. coli and Enterococcus spp. do not correlate well with pathogenic bacteria and protozoa in rainwater tank samples used for potable and non-potable uses in Australia (Ahmed et al., 2010). Such findings raise serious questions regarding the validity of fecal indicator bacteria and consequent health safety. The absence of fecal indicators in samples where the pathogens were detected could be due to the fact that rapid inactivation of fecal indicators may occur in bottled water during storage. For example, Ducluzeau et al. (1976) found that high numbers of E. coli (i.e., $10^{5}-10^{7}$ per $\mathrm{mL}$ ) can disappear within four days, although, it has been reported that E. coli in bottled water may persist for 20 to 70 days (Burge and Hunter 1990; Obiri-Danso et al., 2003). Past research studies have also found that $A$. hydrophila and E. coli O157:H7 can survive as long as 150-300 days in bottled water (Kerr et al., 1999; Messi et al., 2002).

\section{Conclusion}

The above findings underline the fact that bottled water sold in Dhaka, Bangladesh are highly variable in terms of microbiological quality. Presence of fecal indicators and potential bacterial pathogens are alarming. The current research study findings need to be viewed in the context that in Bangladesh diarrhoeal diseases, namely, cholera due to poor water quality and sanitation is a serious health con-

Table 3 - Relationships between fecal indicators numbers and PCR positive and negative results of the pathogens in bottled water samples using binary logistic regression analysis.

\begin{tabular}{lcc}
\hline \multirow{2}{*}{ Parameters } & \multicolumn{2}{c}{ Binary logistic regression } \\
\cline { 2 - 3 } & $R$-square & Odd ratio \\
\hline Fecal indicators vs. A. hydrophila lip gene & 0.07 & 0.985 \\
Fecal indicators vs. Salmonella invA gene & 0.04 & 1.110 \\
Fecal indicators vs. Shigella ipaH gene & 0.07 & 0.999 \\
Fecal indicators vs. P. aeruginosa ETA gene & 0.05 & 0.996 \\
\hline
\end{tabular}

$\mathrm{p}$ value for the model chi-square was $<0.05$, and the confidence interval for the odds ratio did not include 1.0.

Greater odds ratios indicate a higher probability of change in the dependent variable with a change in the independent variable. 
cern. For example, a total of 201,762 cases, and 87 diarrhoea related deaths reported during the flood of 2004 (Akram and Zamman 2004). This is compounded by the fact that Bangladesh has a very low average per capita income, and the purchase of bottled water poses a further financial burden on its most vulnerable people. Therefore, in a country such as Bangladesh where the quality of tap water is uncertain, it is recommended that there should be stringent regulation of bottled water quality whilst boiled tap water could be a safe alternative. It is important that consumers are aware that the perception that bottled water is always safer than tap water can be misleading as the former can also contain the same microorganisms commonly found in tap water.

\section{Acknowledgments}

This study was funded by Queensland Department of Environment and Resource Management (DERM). This was a joint project between DERM, Queensland University of Technology (QUT) and the Independent University of Bangladesh (IUB). We thank IUB for providing laboratory space.

\section{References}

Ahmed W, Goonetilleke A, Gardner T (2010) Implications of faecal indicator bacteria for the microbiological assessment of roof-harvested rainwater quality in Southeast Queensland, Australia. Can J Microbiol 56:471-479.

Akram K, Zamman K (2004) Emergency and Humanitarian Action South East Asian Region - World Health Organization, Bangladesh, Flood Situation Report 22 August 2004. Ministry of Food and Disaster Management, Flood Control and Monitoring Centre, Government of Bangladesh.

Bartram J, Cotruvo J, Exner M, Fricker C, Glasmacher A (2004) Heterotrophic plate count measurement in drinking water safety management. Report of an expert meeting Geneva, 24-25 April 2002. Int J Food Microbiol 92:241-247.

Bharath J, Mosodeen S, Motilal S, Sandy S, Sharma S, Tessaro T, Thomas K, Umamaheswaran M, Simeon D, Adesiyun A (2003) Microbial quality of domestic and imported brands of bottled water in Trinidad. Int J Food Microbiol 81:53-62.

Blake PA, Rosenberg ML, Florencia J (1977) Cholera in Portugal, 1974. II. Transmission by bottled mineral water. Am J Epidemiol 105:344-348.

Burge SH, Hunter PR (1990) The survival of enteropathogenic bacteria in bottled mineral water. Rivista Itaianal D'Igiene 50:401-406.

Cascón A, Anguita J, Hernanz C, Sánchez M, Fernández M, Naharro G (1996) Identification of Aeromonas hydrophila hybridization group 1 by PCR assays. Appl Environ Microbiol 62:1167-1170.

Chakraborti D, Rahman MM, Das B, Murrill M, Dey S, Mukherjee SC, Dhar RK, Biswas BK, Chowdhury UK, Roy S, Sorif S, Selim M, Rahman M, Quamruzzaman Q (2010) Status of groundwater arsenic contamination in Bangladesh: A 14 years study report. Water Res 44:5789-5802.

Chiu CH, Ou JT (1996) Rapid identification of Salmonella serovars in feces by specific detection of virulence genes, inv $A$ and $s p v C$, by an enrichment broth culture - multiplex PCR combination assay. J Clin Microbiol 34:2619-2622.

Ducluzeau R, Bochand JM, Dufrense S (1976) Longevity of various bacterial strains of intestinal origin in gas-free mineral water. Eur J Appl Microbiol 3:227-236.

European Community (1980) Council Directive no.80/777/EEC of 15 July 1980 on the approximation of the laws of the member states relating to the exploitation and marketing of natural mineral waters. Off J Europ Comm L 229:1-10.

Hunter PR, Burge SH, Hornby H (1990) An assessment of the microbiological safety of bottled mineral waters. Rivista Italiana d' Igiena 50:394-400.

Islam MS, Brooks A, Kabir MS, Jahid IK, Islam MS, Goswami D, Nair GB, Larson C, Yukiki W, Luby S (2006) Faecal contamination of drinking water sources of Dhaka city during the 2004 flood in Bangladesh and use of disinfectants for water treatment. J Appl Microbiol 103:80-87.

Jamir M (2009) Accessing safe drinking water. The Daily Star, Dhaka, Bangladesh. September 26, 2009.

Kassenga GR (2007) The health-related microbiological quality of bottled drinking water sold in Dar es Salaam, Tanzania. J Water Health 5:179-185.

Khan AA, Cerniglia CE (1994) Detection of Pseudomonas aeruginosa from clinical and environmental samples by amplification of the exotoxin A gene using PCR. Appl Environ Microbiol 60:3739-3745.

Khan MR, Saha ML, Kibria AHMG et al. (1992) A bacteriological profile of bottled water sold in Bangladesh. World J Microbiol Biotechnol 8:544-545.

Kerr M, Fitzgerald M, Sheridan JJ, McDowell DA, Blair IS (1999) Survival of Escherichia coli O157:H7 in bottled natural mineral water. J Appl Microbiol 87:833-841.

Korzeniewska E, Filipkowska Z, Zarnoch D, Tworus K (2005) Survival of Escherichia coli and Aeromonas hydrophila in non-carbonated mineral water. Pol J Microbiol 54:Suppl:35-50.

Leclerc H, Mossel DAA, Savage C (1985) Monitoring non-carbonated ('still') mineral waters for aerobic colonization. Int J Food Microbiol 2:341-347.

Legnani P, Leoni E, Raquano S, Turin D, Valenti C (1999) Survival and growth of Pseudomonas aeruginosa in natural mineral water: A 5-year study. Int J Food Microbiol 53:153-158.

Messi P, Guerrieri E, Bondi M (2002) Survival of an Aeromonas hydrophila in an artificial mineral water microcosm. Water Res 36:3410-3415.

Obiri-Danso K, Okore-Hanson A, Jones K (2003) The microbiological quality of drinking water sold on the streets in $\mathrm{Ku}-$ masi, Ghana. Lett Appl Microbiol 37:334-339.

Pavia AT (1987) Travel to the Soviet Union: Is diarrhoea a risk? JAMA 258:1661.

Rivilla RF, Gonzalez C (1988) Simplified methods for the microbiological evaluation of bottled natural mineral waters. $\mathrm{J}$ Appl Bacteriol 64:273-278.

Rosenberg FA (2003) The microbiology of bottled water. Clin Microbiol Newsletter 25:41-43.

Svagzdiene R, Lau R, Page RA (2010) Microbiological quality of bottled water brands sold in retail outlets in New Zealand. Wat Sci Technol 10:689-699.

Thiem VD, Sethabutr O, Seidlein LV, Tung TV, Canh DG, Chen BT, Tho LH, Lee H, Houng HS, Hale TL, Clemens JD, Ma- 
son C, Trach DD (2004) Detection of Shigella by a PCR assay targeting the $i p a H$ gene suggests increased prevalence of Shigellosis in Nha Trang, Vietnam. J Clin Microbiol 42:2031-2035.

Venieri D, Vantarakis A, Komninou G, Papapetropoulou M (2006) Microbiological evaluation of bottled non-carbonated ("still") water from domestic brands in Greece. Int J Food Microbiol 107:68-72.

Warburton DW, Dodds KL, Burke R, Johnston MA, Laffey PJ (1992) A review of the microbiological quality of bottled water sold in Canada between 1981 and 1989. Can J Microbiology 38:12-19.

Warburton DW, Bowen B, Konkle A (1994) The survival and recovery of Pseudomonas aeruginosa and its effect upon salmonellae in water: Methodology to test bottled water in Canada. Can J Microbiol 40:987-992.

WHO (2004) Guidelines for Drinking Water Quality. 3rd edition. World Health Organization, Geneva.

All the content of the journal, except where otherwise noted, is licensed under a Creative Commons License CC BY-NC. 